\title{
A GLOBAL OXYGEN ISOTOPE MODEL - SEMI-EMPIRICAL, ZONALLY AVERAGED
}

\author{
by
}

\author{
D.A. Fisher and B.T. Alt
}

(Polar Continental Shelf Project, Energy, Mines and Resources, 880 Wellington St., Ottawa, Ontario K1A 0E4, Canada)

\section{ABSTRACT}

A simple model, which is zonally averaged, for the transport of atmospheric water vapour is presented which uses as input the zonally averaged evaporation field and the mean meridional travel distance of tropospheric water vapour as functions of latitude. The model demonstrates that for polar regions each of the $10^{\circ}$ latitude strips poleward of $25^{\circ}$ is of equal importance as a moisture source. The model is used to predict zonal averages of $\delta\left({ }^{18} \mathrm{O}\right)$ for the present day and $18 \mathrm{ka} \mathrm{BP}$. Both annual average values and seasonal amplitudes are presented and compared to observations. Sea-ice cover is an important factor in determining both annual averages and seasonal amplitudes today and at $18 \mathrm{ka}$ BP. An earlier model (Jouzel and others 1983) linking $8\left({ }^{18} \mathrm{O}\right)$, the deuterium excess, and sea-salt content in an Antarctic ice core to the relative humidity of the source region is based on a single-source atmospheric water-vapour cycle type model and is re-valuated using the present model.

\section{INTRODUCTION}

The ${ }^{18} \mathrm{O} /{ }^{16} \mathrm{O}$ ratio is given in terms of the unitless variable $8\left({ }^{18} \mathrm{O}\right.$ ) (in $\%$, and referred to hereafter as $\delta$ ) and has been used extensively to study the movement of atmospheric water vapour. Oxygen isotope records from ice cores have been used previously to provide local temperature histories at polar sites (Dansgaard and others 1973, Barkov and others 1977, Budd and Morgan 1977, Paterson and others 1977, Lorius and others 1979). It is known that up to seven non-temperature effects can alter the $\delta$ content of precipitation at a given site (Dansgaard and others 1973, Fisher 1979), but the assumption has held that the local site temperature remains as a strong(est) signal in the $\delta$ time series. This assumption rests on a view that most water vapour arriving at polar sites is transported from the warm tropics ( 10 to $25^{\circ} \mathrm{N}$ or $\mathrm{S})$, where evaporation rates and sea surface temperatures are high (Dansgaard and others 1973, Merlivat and Jouzel 1979). In the simplest form of the theory, isotopic fractionation en route follows the Rayleigh condensation process from a limited mass of vapour, and the $\delta\left({ }^{18} \mathrm{O}\right)$ of the condensate at a site with temperature $T$ is

$$
\delta=\left[\alpha F_{v}{ }^{\left(\alpha_{m}-1\right)}-1\right]\left[1+\delta_{v}^{0}\right]+\delta_{v}^{0}
$$

where $F_{v}=y / y_{0}$ with $y_{0}$ and $y$ being the saturation mixing ratios of water vapour at the initial condensation temperature $T_{O}$ and site temperature $T, \alpha, \alpha_{0} \alpha_{m}$ are the
fractionation coefficients (Majoube 1971) for ${ }_{18} O_{0}$ at $T, T_{0}$ and $\left(\mathrm{T}+\mathrm{T}_{0}\right) / 2$ respectively. $\delta_{\mathrm{v}}^{\mathrm{O}}$ is $\delta$ for the initial vapour mass at $\mathrm{T}_{0}$ and is usually taken as $\left(1 / \alpha_{0}-1\right)$ which is close to -0.01 (i.e. $-10 \%$ ). Other factors influence $\delta_{\mathrm{v}}^{0}$ (Merlivat and Jouzel 1979), but for now we assume $\delta_{\mathrm{v}}^{0}=$ $-10 \%$ o.

All the variables in Equation (1) are functions of either $\mathrm{T}$ or $\mathrm{T}_{0}$, thus $\delta$ itself is only dependent on the site temperature $\mathrm{T}$ and the initial condensation temperature $\mathrm{T}_{0}\left(\mathrm{~T}_{Q_{b}}=+20^{\circ} \mathrm{C}\right.$ for a sea surface temperature of $+25.4^{\circ} \mathrm{C}$, with $80 \%$ humidity and adiabatic cooling of the moist air as it rises). The argument continues that $\mathrm{T}_{0}$ in the tropics is very stable even under ice-age conditions, so that the $\delta$ value of precipitation is principally related to the site temperature $\mathrm{T}$.

\section{PROBLEMS WITH THE THEORY}

Where difficulties with the single-source theory have been encountered, the concept of local water vapour mixing with the tropical has been introduced. For example, Koerner and Russell (1979) and Schriber (unpublished: 54-77) need to add about 20\% local Baffin Bay water to the annual precipitation in the Coburg Island area $\left(76^{\circ} \mathrm{N}, 79^{\circ} 30 \mathrm{~W}\right.$, just east of Devon Island) to account for a $\delta$ too positive for the air temperature. Some difficulties are harder to reconcile with the simple theory. There is evidence (J England personal communication) that the regional air temperatures of northeast Ellesmere Island did not change sharply at the Wisconsin-Holocene $\delta$ transition at $10.5 \mathrm{ka} \mathrm{BP}$. The $10.5 \%$ step in $\delta$ in cores from the Agassiz Ice Cap (Fisher and others 1983) in this area could not have been due to a major sudden warming at the site. The air temperature of northern Ellesmere Island seems to have remained cold until at least $8 \mathrm{ka}$ BP. Uplift curves, dated moraines and driftwood (J England personal communication) suggest that ice retreat on northern Ellesmere Island began slowly in about $8 \mathrm{ka} \mathrm{BP}$ and speeded up around $6.2 \mathrm{ka} \mathrm{BP}$.

Eriksson (1965) pointed out that the simple theory is physically unrealistic and that a global model of $\delta$ should depend directly on many meteorological variables along the whole water cycle (evaporation, precipitation, advective wind velocity, eddy diffusivity, temperature, relative humidity). He developed a set of equations containing all these variables, but data quality prevented him from solving them. Robin (1977) has examined and rejected the assumption that the region of major vapour input for polar sites is the warm tropics. He points out that little or no moisture injected equator-ward of $25^{\circ}$ ever reached the polar regions. A number of authors have presented strong empirical evidence showing the importance of the distance from the closest moisture source in determining the $\delta$ value. For polar regions they have shown that the distance from open water is more influential than temperature in determining the $\delta$ value of the site (Kato and others 1978, Koerner 1979, Punning and others 1980, Bromwich and Weaver 1983).

\section{THE MODEL}

The following model uses zonal averages of evaporation, precipitation, temperature, net meridional vapour flux, and the position of the sea-ice front as input. All sources allowed by the net vapour-flux field contribute towards the precipitation at a given site. Since the model does not include orographic effects and is weighted towards ocean conditions, it generates results that apply to sea-level, island and coastal stations. The impetus of the work is to produce a model that includes the major variables in the water vapour cycle and 
TABLE I. ZONAL AVERAGES NORTHERN HEMISPHERE

\begin{tabular}{llllllll} 
Latitude & $\begin{array}{l}\text { Area } \\
\text { fraction } \\
10^{\circ} \text { strip }\end{array}$ & $\begin{array}{l}\text { Percent } \\
\text { ocean }\end{array}$ & $\begin{array}{l}\text { Ocean evapo- } \\
\text { ration now } \\
\left(\mathrm{g} \mathrm{cm}^{-2} \mathrm{a}^{-1}\right)\end{array}$ & $\begin{array}{l}\text { Average } \\
\text { ocean } \\
\text { temperature } \\
\text { now* }\end{array}$ & $\begin{array}{l}\text { Average air } \\
\text { temperature } \\
\text { now }\left({ }^{\circ} \mathrm{C}\right)\end{array}$ & $\begin{array}{l}\text { Source } \\
\text { weight } \\
\text { now }\end{array}$ & $\begin{array}{l}\text { Average } \\
\text { temperature at } \\
18 \mathrm{kP} \mathrm{BP}^{\circ}\left({ }^{\circ} \mathrm{C}\right)\end{array}$ \\
\hline $80-90$ & 0.015 & 90 & 4.2 & 0 & -23.6 & 5.7 & -34.6 \\
$70-80$ & 0.05 & 70 & 14.5 & 0 & -15.9 & 51.0 & -26.9 \\
$60-70$ & 0.07 & 30 & 33.3 & 3 & -7.2 & 70 & -14.2 \\
$50-60$ & 0.1 & 43 & 49.2 & 7 & 0.5 & 212 & -6.0 \\
$40-50$ & 0.12 & 48 & 87.8 & 15 & 7.5 & 506 & 1.5 \\
$30-40$ & 0.14 & 57 & 135.3 & 20 & 14.0 & 1080 & 10.0 \\
$20-30$ & 0.16 & 63 & 157 & 23 & 20.4 & 1583 & 18.9 \\
$10-20$ & 0.17 & 74 & 152.8 & 25.5 & 25.1 & 1922 & 24.1 \\
$0-10$ & 0.17 & 77 & 119.8 & 26.5 & 25.5 & 1568 & 24.5 \\
\hline
\end{tabular}

*Dietrich and Kalle (1957)

generates reasonable $\delta$ values that are not just dependent on the site temperature.

Consider a target latitude zone width $\Delta \mathrm{x}_{\mathrm{t}}(\mathrm{km})$ and distance $x_{t}(\mathrm{~km})$ from the equator. The moisture falling at $x_{t}$ arrives from all the "upwind" zones. Assume for now that the source zones are closer to the equator than the target site, and let the amount of vapour over the target site $x_{t}$ that originates from a source zone centered at distance $x$ (from the equator) be $y\left(x, x_{t}\right)$. Precipitation over the site removes some fraction $k$ of all available vapour contributions. Then the total precipitation at $x_{t}$ is

$$
P\left(x_{t}\right)=k\left[y\left(x, x_{t}\right) .\right.
$$

The $\delta$ of precipitation due to vapour from a source at $x$ is $\delta\left(x, x_{t}\right)$ and the average $\delta\left(x_{t}\right)$ of all the precipitation at the target site $x_{t}$ is

$$
\delta\left(x_{t}\right)=\sum \delta\left(x, x_{t}\right) \frac{y\left(x, x_{t}\right) k}{P\left(x_{t}\right)} .
$$

Now comes a key assumption. The moisture initially injected into the atmosphere at $\mathrm{x}, \mathrm{y}_{0}(\mathrm{x})$ is taken to be proportional to the area of the source zone $A(x)$, the fraction of ocean in the zone $C(x)$, and the oceanic evaporation rate $E(x)$. Thus $y_{0}(x)=K$. E.A.C., where $K$ is a constant. The amount of vapour left at $x_{t}$ from a given source at $\mathrm{x}$ is

$$
y\left(x, x_{t}\right)=\text { K. E. A. C. } f
$$

where $f=y / y_{0}$, the depletion fraction.

For brevity E.A.C. $=\Im(\mathrm{x})$ and is called the source zone weight. Constants $k$ and $K$ have disappeared in the important weights in Equation (3)

$$
\frac{y\left(x, x_{t}\right) k}{P\left(x_{t}\right)}=\frac{\Im . f}{\Sigma(\Im . f)}
$$

The $\Im=$ E.A.C. weights for the northern hemisphere are obtained from annual zonal averages and appear in Table I for present-day conditions.

The ocean-weighted evaporation rate and the ocean fraction are used to calculate the $\Im$ weights instead of the total zonal evaporation because the model is attempting to generate sea-level, island and coastal $\delta$ values. The assumption behind this is that the most precipitation at such sites originates from the oceans. This is reasonable because most of the northward net meridional vapour flux in the northern hemisphere is over oceans (Peixóto and Starr 1958: fig. 112). In practice the results are not very sensitive to whichever choice of $\mathrm{E}$ is used.

The depletion factor $f$ is derived using the vapour survival time $t(x)$, i.e. the average time that vapour at a given latitude stays aloft. During time $t(x)$, vapour at $x$ can travel some distance, whose meridional component is denoted $\lambda(x)$, and can be thought of as the average meridional survival distance for water vapour at $\mathrm{x}$. There are various estimates of $t(x)$. We use that given by Junge (1963) based on $t(x)=W(x) / P(x)$, where $W$ is the amount of precipitable water and $P$ is the precipitation rate. We define $\lambda(x)$ from the net annual zonally-averaged meridional vapour velocity $\overline{\mathrm{v}}_{\Phi}$ :

$$
\lambda(x)=t(x) \quad \bar{V}_{\Phi}(x)={ }_{s} \bar{Q}_{\Phi} /(P S)
$$

$\overline{\mathrm{V}}_{\Phi}$ has been defined by

$$
\overline{\mathrm{v}}_{\Phi}(\mathrm{x})={ }_{\mathrm{S}} \overline{\mathrm{Q}}_{\Phi} /(\mathrm{WS})
$$

where ${ }_{s} \bar{Q}_{\Phi}$ is the net annual zonally-averaged meridional vapour flux across a latitude line at distance $x$. $W$ is the precipitable water vapour and $S$ the peripheral length of the latitude circle at $x$. Included in ${ }_{s} \bar{Q}_{\Phi}$ are both advective and turbulent, or diffusive, vapour transfer Since $\bar{S}_{s}$ includes transport at all elevations the model will not produce elevation effects in the results. The model should be compared to sea-level observations only.

Estimates of ${ }_{s} \bar{Q}_{\phi}$ and $W$ come from Peixóto and Starr (1958) and are listed in Table II along with $t(x)$ and $\lambda(\mathrm{x})$.

Figure 1 shows the mean annual meridional survival distance $\lambda(x)$ based on data for one year (Peixóto and Starr 1958). Positive values of $\lambda$ indicate northward vapour transport and negative values southward. This figure has two node points $\mathrm{S}_{0}$ and $\mathrm{N}_{0}$, where $\lambda=0$. More recently published data by Peixóto and Oort (1983), based on data for ten years, show that $\lambda$ remains large and positive as far as $80^{\circ} \mathrm{N}$. Their data also show the maximum of $\lambda$ in the northern hemisphere to be shifted 


\section{TABLE II. ANNUAL MERIDIONAL SURVIVAL TIMES AND LENGTHS} NORTHERN HEMISPHERE

\begin{tabular}{|c|c|c|c|c|c|c|}
\hline Latitude & $\begin{array}{l}\text { Net meridional } \\
\text { flux across a } \\
\text { latitude band } \\
\qquad \overline{\mathrm{Q}}_{\sigma} \\
\left(10^{8} \mathrm{~kg} \mathrm{~s}^{-1}\right)\end{array}$ & $\begin{array}{l}\text { Peripheral } \\
\text { length } \\
\mathrm{S} \\
\left(10^{7} \mathrm{~m}\right)\end{array}$ & $\begin{array}{l}\text { Precipitable } \\
\text { water } \\
\text { W } \\
\left(\mathrm{kg} \mathrm{m}^{-2}\right)\end{array}$ & $\begin{array}{l}\text { Mean meridional } \\
\text { vapour } \\
\text { velocity } \\
\qquad \overline{\mathrm{v}}_{\varnothing} \\
\left(\mathrm{m} \mathrm{s}^{-1}\right)\end{array}$ & $\begin{array}{l}\text { Mean } \\
\text { residence } \\
\text { time } \\
\mathrm{t} \\
\text { (d) }\end{array}$ & $\begin{array}{l}\text { Mean } \\
\text { travel } \\
\text { distance } \\
\quad \lambda \\
(\mathrm{km})\end{array}$ \\
\hline 80 & -0.11 & 0.69 & 4.8 & -0.33 & 14 & -399 \\
\hline 70 & 0.54 & 1.37 & 6.1 & 0.65 & 10 & 562 \\
\hline 60 & 2.36 & 2.0 & 9.6 & 1.23 & 8 & 850.4 \\
\hline 50 & 5.32 & 2.57 & 13.3 & 1.56 & 6.3 & 850.5 \\
\hline 45 & 5.80 & 2.82 & 15.3 & 1.34 & 6.4 & 742 \\
\hline 40 & 5.46 & 3.06 & 17.7 & 1.01 & 7.5 & 653 \\
\hline 30 & 2.91 & 3.46 & 24.0 & 0.35 & 10 & 302 \\
\hline 20 & -2.7 & 3.75 & 30.8 & -0.23 & 11.5 & -229 \\
\hline 10 & -6.16 & 3.93 & 38.3 & -0.41 & 9.5 & -336 \\
\hline 0 & 0 & 3.99 & 43.9 & 0 & - & 0 \\
\hline
\end{tabular}

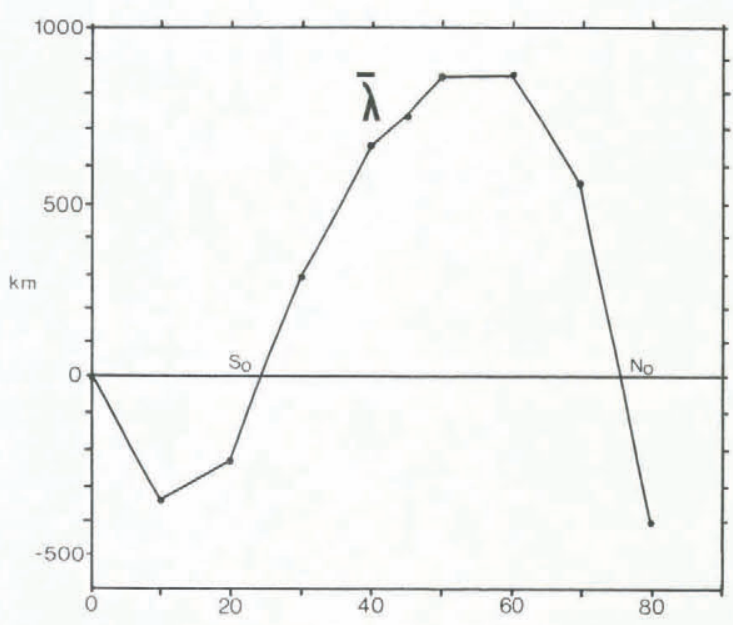

Fig.1. The zonally-averaged annual meridional survival distance of water vapour. $\mathrm{S}_{0}$ and $\mathrm{N}_{0}$ are the node points where in theory the moisture goes up and all comes down on the same spot.

south, and the $S_{0}$ point to remain as it is. Under the formalization of this model precipitation at $S_{0}$ all originates locally. In reality, the nodal point moves and precipitation at $\mathrm{S}_{0}$ comes from sources north and south of $\mathrm{S}_{\mathrm{O}}$.

The following approximation is used to estimate $\lambda(x)$ north of $\mathrm{S}_{\mathrm{O}}$ in Figure 1:

$$
\lambda(x)=\lambda^{*}\left[1-\left[\frac{x-x^{*}}{B}\right]^{2}\right]
$$

where $x^{*}$ is the symmetry point $(=5820 \mathrm{~km}), \lambda^{*}$ is the maximum $\lambda(=1450 \mathrm{~km})$, and $B$ is half the width between the intercepts of the parabola $(=3600 \mathrm{~km})$. The $\lambda^{*}$ value from Figure 1 is seen to be $900 \mathrm{~km}$, but the larger value above is used (the figure of $900 \mathrm{~km}$ is a total zonal average). Over the oceans the northward vapour flux is larger and thus the $\lambda^{*}$ appropriate to the ocean-weighted model is larger, besides by experiment the constants listed for Equation (7) give the best results. The constants of Equation (7) result in positive values of $\lambda$ between 21 and $85^{\circ} \mathrm{N}$. If one could follow an amount of water vapour $\mathrm{y}_{0}(\mathrm{x})$ originating from a zonal band centered at $\mathrm{x}>\mathrm{S}_{0}$, it would move northward and be depleted according to

$$
d y / d x=-y / \lambda(x) .
$$

If $\lambda$ were a constant one would get the simple e-folding depletion relation $y / y_{0}=e^{-x / \lambda}$. With $\lambda(x)$ given by Equation (7) one gets the depletion fraction at target $x_{t}$ of vapour originating at $\mathrm{x}$

$f\left(x, x_{t}\right)=y / y_{0}=\left\{\frac{\frac{1-\left(x^{*}-x\right) / B}{1+\left(x^{*}-x\right) / B}}{\frac{1-\left(x^{*}-x_{t}\right) / B}{1+\left(x^{*}-x_{t}\right) / B}}\right\}^{B / 2 \lambda^{*}}$

The relative depletions $f=y / y_{0}$ go into Equations (5), (3), and (1) so that $\delta$ at site $x_{t}$ can be calculated. The values of $\alpha$ of Equation (1) are changed here to apparent or effective fractionation coefficients $\alpha_{e}$ (Eriksson 1965, Merlivat and Jouzel 1979) by

$$
\alpha_{e}=\alpha /\left\{1+(\alpha-1)\left(y_{e} / y\right)\right\}
$$

Here $\alpha$ is "corrected" to take account of the unprecipitated liquid drop content $y_{e}$ in the air mass. $y_{e} / y$ is typically 0.2 (Eriksson 1965) and is a constant here. Junge (1977) points out, however, that $\mathrm{y}_{\mathrm{e}} / \mathrm{y}$ can vary from 0.1 in the tropics to 
over 0.5 in polar areas. The relative zonal-average precipitation rates can be calculated from Equations (9), (2) and (4).

\section{APPLICATION OF THE MODEL}

Figure 2 displays the $f \Im$ and $\delta\left(x, x_{t}\right)$ functions for a target zone centered at $75^{\circ} \mathrm{N}$. The $\mathrm{f} \Im$ curve shows the relative contributions of the source zones to precipitation at $75^{\circ} \mathrm{N}$, and demonstrates that all the source zones between 30 and $75^{\circ} \mathrm{N}$ supply significant amounts of vapour to $75^{\circ} \mathrm{N}$. In particular the "local water" zone between 65 and $75^{\circ} \mathrm{N}$ contributes about $25 \%$ of the total precipitation. This fraction is in agreement with the conclusions of Koerner and Russell (1979) and Schriber (unpublished) about the origins of precipitation at sea level for northern Baffin Bay.

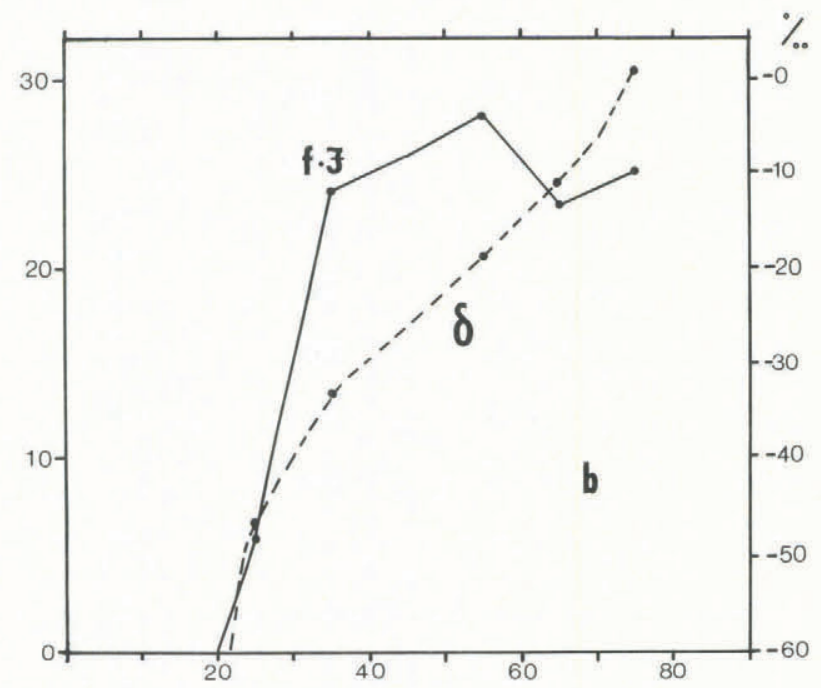

Fig.2. The dashed curve is the $\delta$ of modern precipitation contributions arriving at $75^{\circ} \mathrm{N}$ from various $10^{\circ}$ latitude strips and the solid curve is the $f \Im$ product.

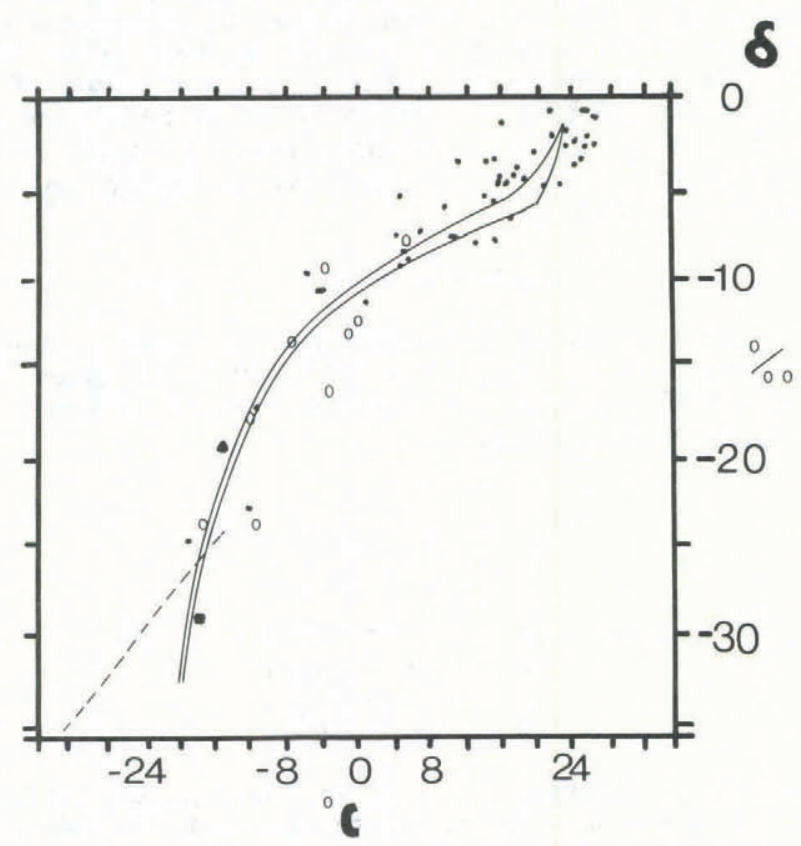

Fig.3(a). Predicted $\delta$ vs. temperature for coastal and island sites from Yurtsever (1975): solid circle, Dansgaard and others (1973): open circle, Koerner and Russell (1979): solid triangle, and $M$ Jeffries (personal communication): solid square. The solid lines are the predictions using as temperatures the zonal averages from Sellers (1967). The dashed line is the ice cap temperature relationship of Dansgaard and others (1973). The upper and lower solid lines assume smooth and rough source oceans, respectively.

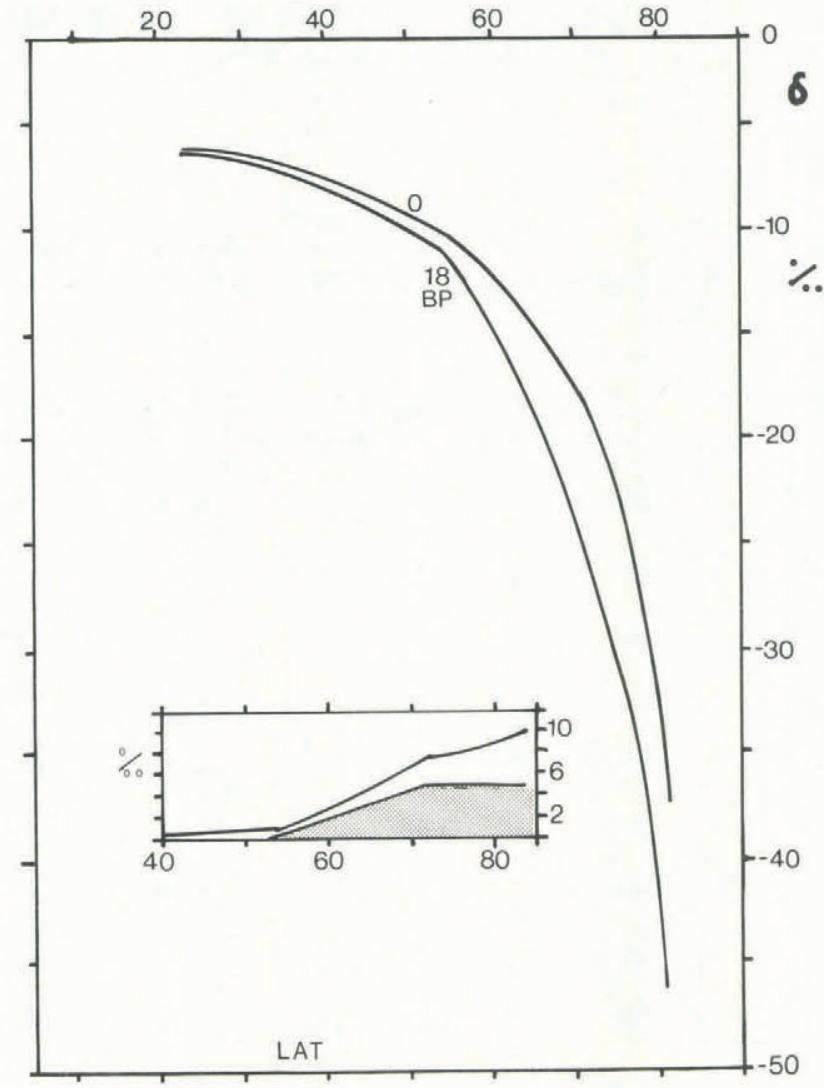

Fig.3(b). Predicted annual average $\delta$ for present conditions $\phi \mathrm{K}$ and hypothetical conditions $18 \mathrm{ka}$ BP, both as functions of latitude. Inset shows predicted $\left(\delta_{\phi K}-\delta_{18 \mathrm{~K}}\right)$ as function of latitude. The shaded portion of the difference is that due to the proposed shift in the annual mean position of the sea-ice front.

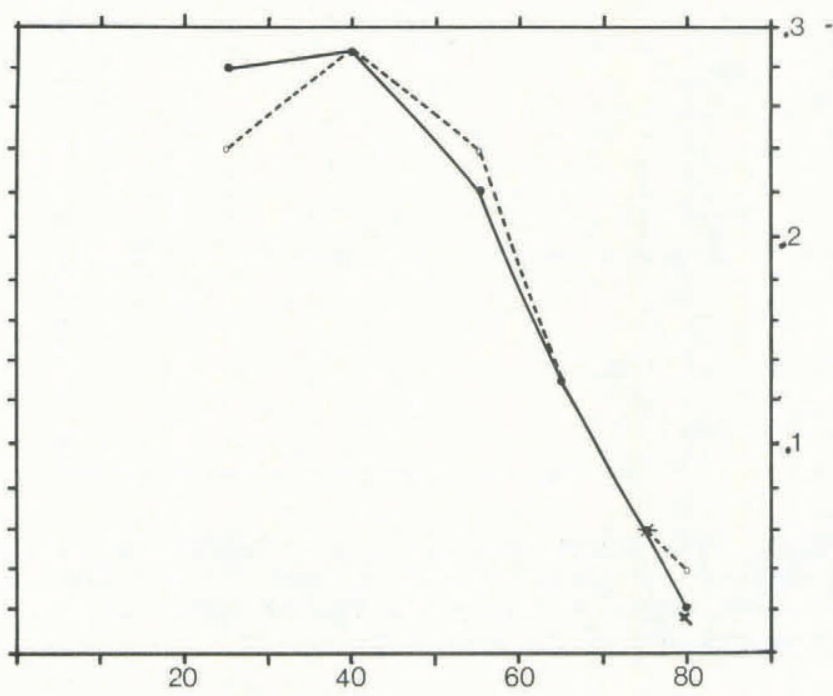

Fig.3(c). Precipitation (normalized) zonal averages. The dashed line represents measured values; the solid line is the model prediction for present conditions.

Figure 3(a) shows that values of $\delta$ estimated from the model (solid line) run through the measured points ( $\delta$, temperature) from island and coastal stations (solid circle: Yurtsever 1975; open circle: Dansgaard and others 1973, coastal sites), and some coastal sites in the Canadian Arctic Islands. Comparison to marine values of $\delta$ is appropriate because of the model parameters used and the dominant meridional vapour flux being mainly marine. The points from Yurtsever's plot that are described as "suffering" from the amount effect (Dansgaard 1964) are not 
included in Figure 3(a). The model temperatures are those zonal averages taken from Sellers (1967) and listed in Table I. Model values of $\delta$ vs. latitude appear in Figure 3(b). No effort is made here to calculate values of $\delta$ outside the latitude range 20 to $80^{\circ} \mathrm{N}$, although this can be done by inserting different constants in Equation (7) and remembering that the vapour flux is from north to south. One can see immediately that if the $\lambda(x)$ function was constant in time, local $\delta$ maxima should occur at $S_{0}$ because $\lambda=0$ and all the precipitation would be local. The calculated maximum at $\mathrm{S}_{0}$ is $-1.3 \%$. In reality $\mathrm{S}_{0}$ is an annual average position, and seasonal, secular, and random movement of $\mathrm{S}_{O}$ would produce a blurred or scattered maximum at $S_{0}$. The Greenland ice-cap line $\delta\left({ }^{18} \mathrm{O}\right)=0.62 \mathrm{~T}-15.2 \%$ (Dansgard and others 1973) is plotted as a dashed line in Figure 3(a). These stations would not be expected to fall on the model line or the coastal marine line because the $\mathrm{d} \delta / \mathrm{dT}$ relation for them is probably determined by the orographic-adiabatic mechanism described by Dansgaard and others (1964, $1973)$. Thus, the values of $\delta$ on the ice cap are
determined by the $\delta$ of the vapour delivered to the coast of Greenland by the model, and then by the mechanism for adiabatic orographic depletion. Once the top of an ice cap is reached the non-adiabatic depletion mechanisms can become important again (Koerner and Russell 1979).

Figure 3(c) shows that the predicted precipitation (solid line) matches the measured values (broken line, Sellers (1967)). The curves are all normalized because the model produces relative values of $P\left(x_{f}\right)$. In the Queen Elizabeth Islands, Canada (latitude $>72^{\circ} \mathrm{N}$ ), the predicted precipitation matches more precisely the regional precipitations measured by Koerner (1979) (see crosses on Fig.3(c)). The predicted precipitation should be close to the actual values because the $t(x)$ function from Junge (1963) is calculated using zonal averages of precipitation. The agreement is thus a check of internal consistency.

\section{SEASONAL $\delta$ VARIATIONS}

The seasonal latitude cycle in temperature $T(x)$, evaporation $E(x)$ and $e$-folding length $\lambda(x)$ will produce a seasonal $\delta$ cycle at any given target site. For a first look at the predicted seasonal $\delta$ cycle, the annual average $\lambda(x)$ function is used along with estimates of seasonal zonal averages of $T$, which are the seasonal temperature amplitudes in Lamb (1972: 145) weighted towards the oceans. The annual average $\mathrm{E}$ field is used except that $\mathrm{E}$ $=0$ over sea ice. Since most of the measurements of the seasonal $\delta$ cycle north of $50^{\circ} \mathrm{N}$ are from stations on either side of Baffin Bay, we decided to use the model in this context by using the seasonal sea-ice cycle from Baffin Bay. In January the sea ice reaches the southern tip of Greenland $\left(60^{\circ} \mathrm{N}\right)$, and in July the bay is free of ice with the nominal northern limit of open Baffin water at $75^{\circ} \mathrm{N}$. Thus, there is a $15^{\circ}$ latitude sea-ice cycle. Also, we assume that sites north of $75^{\circ} \mathrm{N}$ in the Queen Elizabeth Islands and northern Greenland receive no

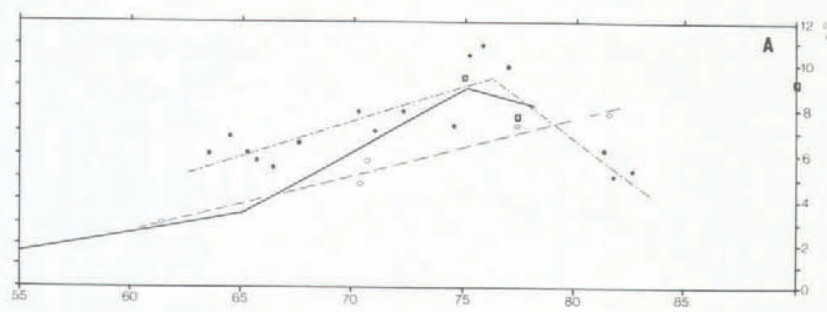

Fig.4. The latitude dependence of the amplitude of the seasonal $\delta$ cycle $\left({ }^{8}\right.$ summer $\left.-\delta_{\text {winter }}\right) / 2$. The solid line is the model prediction. The following symbols represent measurements made at high-elevation ice cap sites from Greenland and the Canadian Arctic: solid circle, coastal sites from Greenland: open circle, Antarctic sites: open square. The (lower) dashed line is a least-squares linear fit to the coastal sites and the (upper) dot-dashed line is for the ice cap sites. Adapted from Fisher and others (1985). moisture from sources between 75 to about $83^{\circ} \mathrm{N}$, this region being mostly land.

Figure 4 summarizes the measured seasonal amplitude $A=\left({ }^{\delta}\right.$ summer $\left.-\delta_{\text {winter }}\right) / 2$ for Greenland and Canadian Arctic ice cap stations, coastal Greenland stations and some Antarctic sites. The dashed lines are linear regressions through the northern ice-cap and coastal stations. The solid line is the model prediction. The model line follows the coastal station line (lower dashed) until about $65^{\circ} \mathrm{N}$, and then rises to meet the ice-cap line near $75^{\circ} \mathrm{N}$ where A reaches a maximum for both model and ice cap. The contribution of the sea-ice cycles to A can be seen immediately by comparing coastal stations at either limit of the sea-ice cycle. At Gronnedal $\left(61^{\circ} \mathrm{N}\right)$, which feels little or no sea-ice effect, $\mathrm{A}=3.3 \%$ and at $75^{\circ} \mathrm{N}$, which gets the full effect, $\mathrm{A}=6.4 \%$. Thus the maximum contribution to $\mathrm{A}$ of a $15^{\circ}$ latitude march in sea ice is about $3.1 \%$, about half of the total $\mathrm{A}$ at $75^{\circ} \mathrm{N}$. With the rough seasonal parameters used here the model predicts a $4.8 \%$ contribution to $\mathrm{A}$ from the
sea-ice cycle and $4 \%$ from the other seasonal variables. The rise of $\mathrm{A}$ in the model above the measured coastal line north of $65^{\circ} \mathrm{N}$ is possibly because the seasonal values of $E$ used are not realistic north of $60^{\circ} \mathrm{N}$; also one cannot hope to reproduce much more than general tendencies from a zonal model even if it is "tuned" to a particular area. The "odd" small measured values of $A$ for the ice-cap sites north of $80^{\circ}$ could be related to the presence of the $\mathrm{N}_{\mathrm{O}}$ mode at $77^{\circ} \mathrm{N}$. Sites north of $\mathrm{N}_{\mathrm{O}}$ receive much of their moisture from the Arctic Ocean.

It is interesting to note that for the Antarctic Robin and Johnsen (1983) have drawn attention to the fact that $\mathrm{A}$ at the coastal site of Syowa (latitude $69^{\circ} \mathrm{S}$ ) is close to that of Mizuho camp (latitude $70^{\circ} 45^{\prime} \mathrm{S}$ ) (Kato and others 1978) and Amundsen-Scott station (latitude $90^{\circ} \mathrm{S}$ ) (Aldaz and Deutsch 1967). The coast in this case is the southern limit of the sea-ice cycle. Robin and Johnsen go on to suggest that the biggest contribution to $\mathrm{A}$ is caused by this cycle. We find this assertion too strong for the northern hemisphere. At $75^{\circ} \mathrm{N}$ only $50 \%$ of coastal A is due to the sea-ice cycle. The values of $A$ in the Antarctic are plotted in Figure 5 with the Syowa point placed at $75^{\circ} \mathrm{S}$, which is the poleward limit of the northern sea-ice cycle. The A-latitude relationship poleward of $80^{\circ}$ might be different for the two hemispheres because in the north there are moisture sources north of $80^{\circ}$, but none in the Antarctic south of $70^{\circ}$.

\section{MODEL APPLIED TO HYPOTHETICAL ICE-AGE CONDITIONS}

In order to try out the model on some hypothetical conditions $18 \mathrm{ka}$ ago, we assume that the annual average $\lambda(x)$ is as today. $T(x)$ is derived by altering today's temperature averages according to the CLIMAP $18 \mathrm{ka} \mathrm{BP}$ temperature for the Atlantic Ocean (CLIMAP Project Members 1976). In the high Arctic the $18 \mathrm{ka}$ BP temperature is obtained from the climatic $\delta$ shift of the Devon Island ice core (Paterson and others 1977). This $7 \%$ shift suggests a temperature $11^{\circ} \mathrm{C}$ cooler than today. Although this use of $\delta$ to estimate the $18 \mathrm{ka} \mathrm{BP}$ temperature is circular, we note that the $11^{\circ} \mathrm{C}$ fits in as a reasonable northward extrapolation of the CLIMAP ocean temperature changes. Also, the values of $\delta$ in the model at high Arctic target sites are not markedly sensitive to the temperature at the target site. These 18 ka BP temperatures are listed in Table I. In addition, we assume an $18 \mathrm{ka}$ BP sea-ice cycle having the January ice front at $55^{\circ} \mathrm{N}$ and July at $65^{\circ} \mathrm{N}$. The annual average position is about $10^{\circ}$ farther South than today. The calculated mean annual values of $\delta$ are shown in Figure 3(b) plotted against latitude, and the inset shows the $\left(\delta_{\phi k}-\delta_{18 k}\right)$ difference. The $\delta$ differences are about the right amount. Table III lists this difference for the ice cores drilled north of $60^{\circ} \mathrm{N}$. The $\delta$ difference for the Barnes Ice Cap (Hooke and Clausen 1982) is complicated by extreme changes in the elevations of the ice-flow line, present-day melt on the surface and the non-continuous $\delta$ profile available. Recent flow-model calculations suggest that during 


\section{$\boldsymbol{\delta}_{18} \%$}

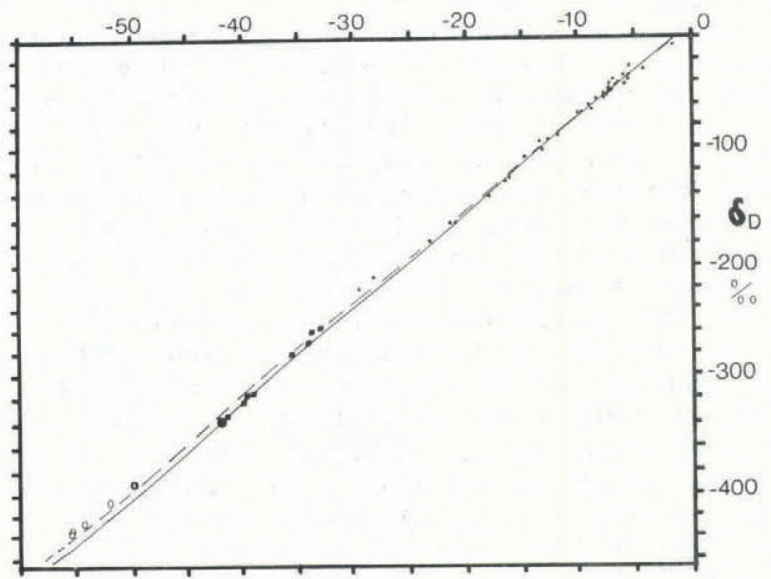

Fig.5(a). $\delta\left({ }^{18} \mathrm{O}\right)$ vs. $\delta(\mathrm{D})$. The model produces the solid line. The dashed line represents Dansgaard's (1964) empirical line, small circles are Dansgaard's points, solid squares are Byrd station ice-core averages (Epstein and others 1970), large open circle is Dome C ice core, adapted from Jouzel and others (1982), and heavy closed circle is Horlick Mountains (Dansgaard 1964).

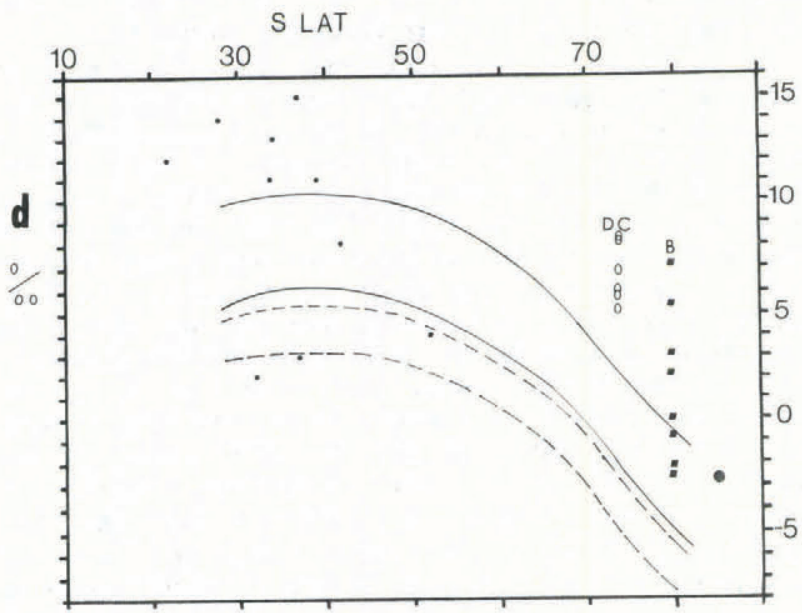

Fig.5(b). The southern-hemisphere predicted deuterium excess $d=\delta(D)-8 \delta\left({ }^{18} \mathrm{O}\right)$ vs latitude for smooth ocean curves, upper are for a relative humidity of $80 \%$ and the lower of $90 \%$. The measured southern hemisphere values are symbolized as in Figure 5(a).

the late Wisconsin the flow lines through the Barnes area originated $2400 \mathrm{~m}$ a.s.1. (N Reeh personal communication). This underlines the caution involved in comparing the predictions of a zonally-averaged sea-level model to the differences measured at ice-cap sites at high elevations where so many other effects related to the ice cap can influence the values of $\delta$. This rough model only indicates the rough order of magnitude of the $\delta$ difference and suggests that $\left(\delta_{\curvearrowleft}-\delta_{18 k}\right)$ has some inherent latitude variance.

\section{DEUTERIUM-OXYGEN 18 RELATIONSHIP}

Up to this point we used Equation (1) which gives an approximation to the precipitation $\delta$ produced by condensation from a limited quantity of vapour from a given source zone. Also we have assumed that the initial vapour $\delta_{v}^{0}$ over the source zone to be a constant $-10 \%$. In order to extend this model and examine the $8^{18} \mathrm{O}-$ 6D relationship Equation (1) is replaced by the differential equation developed by Merlivat and Jouzel (1979).

$$
\frac{d \delta}{1+\delta}=\frac{\alpha(\alpha-1) d y+y d \alpha}{\alpha\left(y+\alpha y_{e}\right)}
$$

TABLE III. ICE CORE $\delta$ DIFFERENCES $\left(\delta_{ø \mathrm{~K}^{-}} \delta_{18 \mathrm{~K}}\right)$

$\begin{array}{lccc}\text { Site } & \begin{array}{c}\text { Latitude } \\ \text { north }\end{array} & \begin{array}{c}\text { Present elevation } \\ \text { (m a.s.1.) }\end{array} & \begin{array}{c}\left(\delta_{\varnothing \mathrm{K}}-\delta_{18 \mathrm{~K}}\right) \\ (\% \circ)\end{array} \\ \begin{array}{c}\text { Agassiz } \\ \text { Ice Cap }\end{array} & 81 & 1670 & 8 \\ \begin{array}{c}\text { Camp Century, } \\ \text { Greenland }\end{array} & 77 & 1890 & 11.5 \\ \begin{array}{c}\text { Devon Island } \\ \text { ice cap }\end{array} & 75 & 1830 & 7 \\ \begin{array}{c}\text { Barnes Ice } \\ \text { Cap }\end{array} & 70 & \sim 900 & 19-15^{* *} \\ \begin{array}{c}\text { Dye 3, } \\ \text { Greenland }\end{array} & 65 & 2460 & (9.7-5.7) \\ \end{array}$

* If, as we believe (Fisher and others 1983), a wind scour correction should be applied to all $\delta$ values older than $3500 \mathrm{BP}$, the difference is $10.5 \%$.

** Contains a large flow-line effect (see text); bracketed values are flow-corrected.

*** Dansgaard and others (1982).

where, as before, $y$ is the mixing ratio of water vapour, $\mathrm{y}_{\mathrm{e}}$ is the mixing ratio of liquid droplets in the clouds, and $\alpha$ is the fractionation coefficient for ${ }^{18} \mathrm{O}$ or $\mathrm{D}$.

Their expression for the initial vapour $\delta$ is

$$
\delta_{v}^{o}=\frac{1}{a_{c}} \quad\left[\frac{1-k}{1-k h}\right]-1
$$

where $\alpha_{c}$ is the isotopic fractionation coefficient $\left({ }^{18} \mathrm{O}\right.$ or D) at the sea-surface temperature and $h$ is the relative humidity in the air mass over the ocean. $k$ is the variable related to kinetic (non-equilibrium) fractionation effects in the air-ocean boundary layer. For ${ }^{18} \mathrm{O}$

$$
\mathrm{k}_{18} \mathrm{O} \approx 7 \% \text { for smooth oceans }
$$

and

$$
\mathrm{k}_{18} \mathrm{O} \approx 4 \% \text { for rough oceans }
$$

(Merlivat and Jouzel 1979: fig.2). In addition, they show that for deuterium D

$$
\mathrm{k}_{\mathrm{D}} / \mathrm{k}_{18 \mathrm{O}}=0.88
$$

They define a rough regime as having wind speeds $\geqslant 7$ $\mathrm{ms}^{-1}$ at $10 \mathrm{~m}$ above the surface. Although they quote Eriksson and Bolin (1965) as stating that $95 \%$ of the world's oceans are smooth, they calculate an ocean-weighted value for $\mathrm{k}_{18} \mathrm{O}$ of $4.8 \%$ o. The present model was run with two ${ }^{k_{18}} \mathrm{O}$ extremes of $7 \%$ a and $4 \%$.

The independent variable in the integration is $\mathrm{x}$, the distance from the equator, and Equation (11) is used in the form

$\frac{d \delta}{d x}=(1+\delta)\left[\alpha(\alpha-1) \frac{d y}{d x} \frac{1}{y}+\frac{d \alpha}{d x}\right] / \alpha\left[1+\alpha \frac{y_{e}}{y}\right]$

with $\frac{d \alpha}{d x}=\frac{d \alpha}{d T} \frac{d T}{d x}$, 
T being the average zonal temperature and $y_{e} / y$ as before is kept at a constant 0.2 . dy/ydx comes from Equations (7) and (8). From the region north of $\mathrm{S}_{0}$ integration starts at $\mathrm{S}_{0}$ and proceeds northward using empirical data from Table I. Figure $5(\mathrm{a})$ shows the $\left(\delta^{18} \mathrm{O}, \delta \mathrm{D}\right)$ points from Dansgaard (1964: fig.10) (dots) along with points from time averages adapted from ice-core data, Byrd core (Epstein and others 1970) (squares), and Dome C (Lorius and others 1979) (ellipses). Dansgaard's (1964) least squares line is the dashed line $\delta(D)=8.18\left({ }^{18} \mathrm{O}\right)+11$. The model points all fall very nearly on their solid least squares line $($ Fig.5(a) $) \delta(D)=8.37 \delta\left({ }^{18} \mathrm{O}\right)+11.9$. The deuterium excess is defined by $d=8(D)-8 \delta\left({ }^{18} \mathrm{O}\right)$.

Jouzel and others (1982) examined the important variables influencing $d$ in the ice core recovered from Dome C, Antarctica. There is a decrease of $4.5 \%$ in d from Holocene to ice age. They concluded that (i) the d excess is conserved from source to target, (ii) d is mainly determined by the relative humidity $h$ of the air over the source ocean, and (iii) the $\mathrm{d}$ shift of $4.5 \%$ from present to ice age is thus due to a change in relative humidity from 80 to $90 \%$.

Using the modern atmospheric and oceanic data for the southern hemisphere and an annual average sea-ice front at $65^{\circ} \mathrm{S}$ (Ackley 1981), the present multi-source zonal model calculates the deuterium excess shown in Figure 5(b) for 80 to $90 \%$ relative humidity and for smooth and rough source oceans. Since both $h$ and $k$ are probably latitude variables the actual d values are likely to be some average of the curves. The sparse "measured" values of $d$ for the southern hemisphere are plotted. Since the zonal model is weighted to the oceans and relevant to sea-level, the model values of $d$ are not really valid for latitudes south of $70^{\circ} \mathrm{S}$. It seems from Figure 5(b) that d presently has a latitude dependence and, furthermore, at any given site $\mathrm{d}$ can be shifted as much as $8 \%$ by altering $\mathrm{k}$ and $\mathrm{h}$ within reasonable limits.

Speculative runs of the model for the southern hemisphere were made assuming ice-age (18 ka BP) air and sea temperatures altered by amounts suggested by CLIMAP Project Members (1976: fig.3) and Robin and Johnsen (1983: chapter 6.3) and taking an average ice-age sea front at $55^{\circ} \mathrm{S}$. The calculated $\mathrm{d}$ values suggest that half of the $4.5 \%$ d change at Dome C could be related to the latitude dependence of $d$. Because of other evidence presented by Jouzel and others (1982) (i.e. higher ice-age salt concentrations and atmospheric model predictions of enhanced storminess), it seems that $k, h$ and their latitude dependence are important in explaining the $d$ shift. Assigning all the $d$ shift to an $h$ change seems to be arbitrary. Of course, a zonal model can only suggest what variables are important in affecting $d$ at any given site. For example, Figure $5(\mathrm{~b})$ shows a change in $\mathrm{d}$ in the Byrd station core of about $8 \%$. The zonal model cannot explain such differences from one longitude to another. Finally, the calculated $\left(\delta_{\phi k}-\delta_{18}\right)$ differences on the coast of Antarctica are about $4 \%$ o, or about half those calculated for northern ice-cap sites. This is in agreement with the ice-core data.

\section{FURTHER WORK}

In principle the theory of this simple latitude-longitude variable model with resolution limited by the resolution of the input data. One could then use the geographical array of ice-core $\delta$ time series stretching back many millenia to validate and test proposed atmospheric models that produced vapour trajectories and the latitude-longitude functions of evaporation E, precipitation $\mathrm{P}$, moisture flux Q, precipitable water $\mathrm{W}$ and temperature $T$. Thus, if one has lost the target site $\delta$ as a simple function of the site temperature, one has gained through the geographical array of $\delta$ time series a powerful and independent set of data to test the state of the whole atmospheric flow pattern. The job is now bigger but even more rewarding.

\section{REFERENCES}

Ackley S F 1981 A review of sea-ice weather relationships in the southern hemisphere. International Association of Hydrological Sciences Publication 131 (Symposium at Cunberra 1979 - Sea Level, Ice and Climatic Change): 127-159

Alcaz L, Deutsch S 1967 On a relationship between air temperature and oxygen isotope ratio of snow and firn in the South Pole region. Earth and Planetary Science Letters 3: $267-274$

Barkov N I, Korotkevich E S, Gordiyenko F G, Kotlyakov V M 1977 The isotipe analysis of ice cores from Vostok station (Antarctica), to the depth of $950 \mathrm{~m}$. International Association of $H_{y}$ drological Sciences Publication 118 (General Assembly of Grenoble 1975 - Isotopes and Impurities in Snow and Ice): 382-387

Bromwich D H, Weaver C J 1983 Latitudinal displacement from main noisture source controls $\delta^{18} \mathrm{O}$ of snow in coastal Antarctica. Nature 301(5896): 145-147

Budd W F, Mo:gan V I 1977 Isotopes, climate and ice sheet dynamics fiom core studies on Law Dome, Antarctica. Internctional Association of Hydrclogical Sciences Publication 118 (General Assembly of Grenoble 1975 - Isclopes and Impurities in Snow and Ice): 312-321

CLIMAP Project Members 1976 The surface of the ice-age Earth. Science 191(4232): 1131-1137

Dansgaard W 1964 Stable isotopes in precipitation. Tellus 16(4): 436-468

Dansgaard W, Johnsen S J, Clausen H B, Gundestrup N 1973 Stable isotope glaciology. Meddelelser om Gronland 197(2)

Dansgaard W and 6 others 1982 A new Greenland deep ice core. Science 218(4579): 1273-1277

Dietrich G, Kalls K. 1957 Allgemeine Meereskunde. Berlin, Borntraeger

Epstein S, Sharp R P, Gow A J 1970 Antarctic ice sheet: stable isotope analyses of Byrd station cores and interhemispheric climatic implications. Science 168(3939): $1570-1572$

Eriksson E 1965 Deuterium and oxygen-18 in precipitation and other natural waters; some theoretical considerations. Tellus 17(4): 498-512

Eriksson E, Bolin B 1965 Oxygen-18, deuterium and tritium in natural waters and their relations to the global circulation of water. In Proceedings of the second Conference on Radioactive Fallout from Nuclear Weapon Tests (AEC): 675-686 (US Atomic Energy Commission. Symposium Series 5)

Fisher D A 1979 Comparison of $10^{5}$ years of oxygen isotope and insoluble impurity profiles from the Devon Island and Camp Century ice cores. Quaternary Research 11(3): 299-305

Fisher D A, Koerner R M, Paterson W S B, Dansgaard W, Gundestrup N, Reeh N 1983 Effect of wind scouring on climatic records from ice-core oxygen-isotope profiles. Nature 301(5897): 205-209

Fisher D A, Reeh N, Clausen H B 1985 Stratigraphic noise in time series derived from ice cores. Annals of Glaciology 7: 76-83

Hooke R LeB, Clausen H B 1982 Wisconsin and Holocene ${ }^{18} \mathrm{O}$ variations, Barnes Ice Cap, Canada. Geological Society of America. Bulletin 93(8): 784-789

Jouzel J, Merlivat L, Lorius C 1982 Deuterium excess in an East Antarctic ice core suggests higher relative humidity at the oceanic surface during the last glacial maximum. Nature 299(5885): 688-691

Junge C E 1963 Air chemistry and radioactivity. New York and London, Academic Press

Junge C E 1977 Processes responsible for the trace content in precipitation. International Association of Hydrological Sciences Publication 118 (General Assembly of Grenoble 1975 - Isotopes and Impurities in Snow and Ice ): 63-77

Kato K, Watanabe O, Satow K 1978 Oxygen isotope composition of the surface snow in Mizuho Plateau. Memoirs of the National Institute of Polar Research. Special Issue 7: 245-254

Koerner R M 1979 Accumulation, ablation, and oxygen isotope variations on the Queen Elizabeth Islands ice caps, Canada. Journal of Glaciology 22(86): 25-41 
Koerner R M, Russell R D $1979 \delta^{18} \mathrm{O}$ variations in snow on the Devon Island ice cap, Northwest Territories, Canada. Canadian Journal of Earth Sciences 16(7): $1419-1427$

Lamb H H 1972 Climate: present, past and future. Vol 1. Fundamentals and climate now. London, Methuen

Lorius C, Merlivat L, Jouzel J, Pourchet M 1979 A 30,000-yr isotope record from Antarctic ice. Nature 280(5724): 644-648

Majoube M 1971 Fractionnement en oxygène 18 et en deutérium entre l'eau et sa vapeur. Journal de Chimie Physique 68: 1423-1436

Merlivat L, Jouzel J 1979 Global climatic interpretation of the deuterium-oxygen 18 relationship for precipitation. Journal of Geophysical Research 84(C8): 5029-5033

Paterson W S B and 7 others 1977 An oxygen-isotope climatic record from the Devon Island ice cap, Arctic Canada. Nature 266(5602): 508-511

Peixóto J P, Oort A H 1983 The atmospheric branch of the hydrological cycle and climate. In Street-Perrott A, Beran $\mathrm{M}$, Ratcliffe $\mathrm{R}$ (eds) Variations in the global water budget. Dordrecht etc, D Reidel Publishing Co

Peixóto J P, Starr V P 1958 Hemispheric humidity conditions during the year 1950. Cambridge, MA, Geophysics Research Directorate of the Air Force. Cambridge Research Centre. Air Research and Development Command: 142 (Contract No AF19(604)-2242)

Punning Ya-M K, Vaykmyae R A, Kotlyakov V M, Gordiyenko F G 1980 Izotopno-kislorodnyye issledovaniya kerna s ledorazdela lednikov Grënf'ord i Frit'of (o. Zapadnyy Shpitsbergen) [Isotope-oxygen investigations of ice cores from the ice divide of Grønfjordbreane and Fridtjovbreen, Vestspitsbergen]. Materialy Glyatsiologicheskikh Issledovaniy. Khronika. Obsuzhdeniya 37: $173-177$

Robin G de Q 1977 Ice cores and climatic change. Philosophical Transactions of the Royal Society of London Ser B 280(972): 143-168

Robin G de Q, Johnsen S J 1983 Atmospheric processes. In Robin $\mathrm{G}$ de $\mathrm{Q}(e d)$ The climatic record in polar ice sheets. Cambridge, Cambridge University Press: 47-52

Schriber G Unpublished Erste Ergebnisse der Isotopenuntersuchungen im Rahmen des North Water Projektes. (Diploma thesis, University of Bern, 1974)

Sellers W D 1967 Physical climatology. Second edition. Chicago and London, University of Chicago Press

Yurtsever Y 1975 Worldwide survey of stable isotopes in precipitation. IAEA. Section of Isotope Hydrology. Report 